\title{
The Compromised, Pre-Diseased or Post-Diseased Terrain, Malaria and Germ Terrain Dualism
}

\author{
Seun Ayoade* \\ Department of Physiology, University of Ibadan, Nigeria
}

Received: 眥July 18, 2018; Published: 眥July 23, 2018

*Corresponding author: Seun Ayoade, BSc (Hons) Physiology, University of Ibadan P.O. Box 22325, Oyo State, Nigeria

\section{Introduction}

The Germ-Terrain duality theory of disease states that the aetiology of certain diseases/diseased states is better explained as a complex interplay between germs and the inherent anatomical/ physiological integrity of the body cells. It argues that the aetiology of certain diseases is not fully explained merely by the presence of germs (Germ Theory) or by a mere loss of cellular integrity (Terrain Theory). As a result, the prevention and treatment of such diseases should focus not just on fighting germs but on maintaining/ restoring the anatomical/physiological cellular integrity. The Germ-Terrain duality theory is a harmonization of the current Germ Theory (popularized by Louis Pasteur) and the hitherto discarded Terrain Theory (popularized by Pierre Bechamp) [1].

If an unhealthy/pre-diseased person is infected with malaria, what happens? What is the effect of malaria in an individual whose anatomical/physiological terrain (integrity wise) has been compromised prior to (or after) infection?

\section{Conditions That Provide Resistance to Malaria}
a) Thalassemias [2]
b) Blood Group 0 [3-6]
c) AIDS
d) Type 2 Diabetes (Disputed) [7-8]
e) Pyruvate kinase deficiency
f) Duffy antigen receptor negativity
g) Gerbich antigen receptor negativity
h) Human leucocyte antigen polymorphisms
i) Cancer [9]
j) Glycophorin A and B protein mutations

Conditions That Provide No Resistance to Malaria, Encourage Malaria to Thrive And/or Are Themselves Adversely Affected by Malaria

a) Blood Group A [10]

b) Pregnancy

c) Hypertension

d) Vitamin A deficiency

e) Excess Iron

f) Vitamin B1 (Thiamine) deficiency [11]

g) Zinc deficiency [12]

h) Folate deficiency [13]

The above show terrain has a role to play in the aetiology of malaria.

\section{References}

1. Ayoade S (2017) Etiology, Epidemiology and Therapeutic History of Malaria Validate Germ-Terrain Duality; Postulates Thereof. J Mol Genet Med 11: 261.

2. Ayoade S (2017) Thalassemias Validate Germ Terrain Duality of Malaria. Health Sci J 11(3): 512.

3. Tewodros Zerihun, Abraham Degarege, Berhanu Erko (2011) Association of ABO blood group and Plasmodium falciparum malaria in Dore Bafeno Area, Southern Ethiopia. Asian Pac J Trop Biomed. Aug 1(4): 289-294.

4. J Alexandra Rowe, Ian G Handel, Mahamadou A Thera, Anne-Marie Deans, Kirsten E Lyke, et al. (2007) Blood group 0 protects against severe Plasmodium falciparum malaria through the mechanism of reduced resetting. PNAS October 30 104(44): 17471-17476.

5. J Alexandra Rowe, D Herbert Opi, Thomas N Williams (2009) Blood groups and malaria: fresh insights into pathogenesis and identification of targets for intervention. Published in final edited form as: Curr Opin Hematol. Nov 16(6): 480-487.

6. Mats Wahlgren (2015) How blood group 0 protects against malaria. Nature Medicine, AOP 9 March. 
7. Pierre Lutgen (2017) Does diabetes have antimalarial properties. Malaria World March 23.

8. I Danquah, FP Mockenhaupt (2010) Type 2 Diabetes Mellitus and Increased Risk for Malaria Infection. Kwame Nkrumah University of Science and Technology. Centre for Disease Control Dispatch 16(10): 1601-1604.

9. Xuan Pham (2016) Negative Link between Malaria Resistance and Cancer Metastasis. Labroots.

10. N Gopal Raj (2015) Malaria: people with blood group A more vulnerable to severe disease. The Hindu March 11.

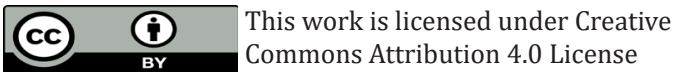

To Submit Your Article Click Here: Submit Article

DOI: $10.32474 /$ PRJFGS.2018.01.000124
11. Anuraj H Shankar (2000) Nutritional Modulation of Malaria Morbidity and Mortality, The Journal of Infectious Diseases, 1 September 182(1): 37-53.

12. WHO (2017) Malaria In pregnant Women.

13. American Heart Association News (2016) Scientists propose a malariahigh blood pressure, AMERICAN HEART ASSOCIATION NEWS Malaria and HIV AIDS.

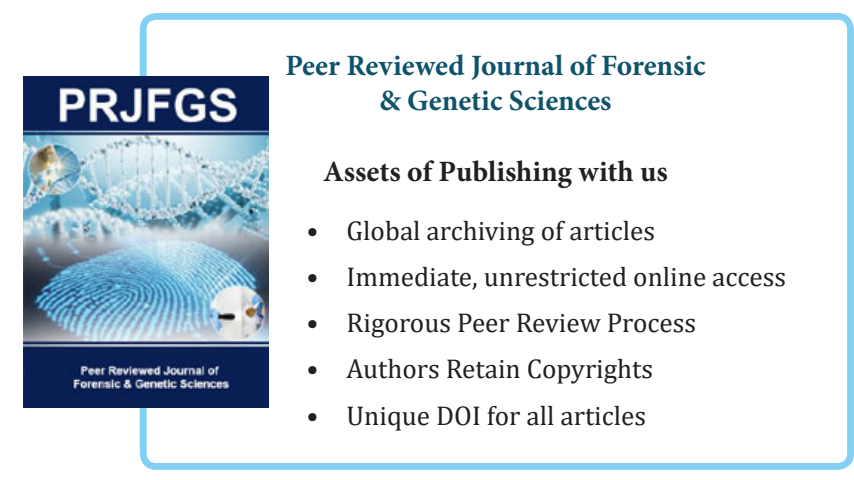

